\title{
Prey size selection, grazing and growth response of the small heterotrophic dinoflagellate Gymnodinium sp. and the ciliate Balanion comatum - a comparative study
}

\author{
Hans Henrik Jakobsen*, Per Juel Hansen \\ Marine Biological Laboratory, Strandpromenaden 5, DK-3000 Helsingør, Denmark
}

\begin{abstract}
Prey selectivity, growth and feeding responses were studied in the ciliate Balanion comatum $(17 \mu \mathrm{m})$ and the heterotrophic dinoflagellate Gymnodinium sp. $(7 \mu \mathrm{m})$. Almost identical prey size spectra were found for the 2 organisms. Optimum prey size was $8 \mu \mathrm{m}$, while the lower and upper limits of prey capture were $\sim 4$ and $10 \mu \mathrm{m}$, respectively. Maximum growth and ingestion rates of $B$. comatum were slightly higher than those of Gymnodinium sp. Threshold prey concentration for growth of $B$. comatum and Gymnodinium sp. was 11 and $17 \mu \mathrm{g} \mathrm{Cl} \mathrm{l}^{-1}$, respectively. At $15^{\circ} \mathrm{C}$, both organisms needed to ingest approx. 1 to $2 \% \mathrm{~h}^{-1}$ of their cell volume in order to sustain basic metabolic activity. Maximum specific clearance was 2 to 3 times higher for the ciliate compared to the dinoflagellate. Gymnodinium sp. survived for a longer time than B. comatum when deprived of prey organisms. Gymnodinium sp. cells were not ingested by $B$. comatum, although they were of a size which is optimal for B. comatum.

KEY WORDS: Balanion comatum - Gymnodinium sp. Prey size spectra Growth - Grazing · Swimming behavior
\end{abstract}

\section{INTRODUCTION}

Heterotrophic dinoflagellates and ciliates are quantitatively important parts of the marine planktonic food web (Smetacek 1981, Lessard 1991). Apart from mineralizing organic matter, they represent a link between primary production and metazooplankton (e.g. Beers \& Stewart 1967). Most marine planktonic ciliates feed on prey which is about 10 times smaller than themselves (Heinbokel 1978, Jonsson 1986, Verity 1991). However, raptorial ciliates occur in the plankton (Montagnes et al. 1988, Nielsen \& Kiørboe 1994). Heterotrophic dinoflagellates are raptorial feeders capable of feeding on prey items of their own size (Jacobson \& Anderson 1986, Hansen 1992). Large dinoflagellates (>20 $\mathrm{mm}$ ) have been found to feed on mainly chainforming diatoms, dinoflagellates, other flagellates

•E-mail: hhjakobsen@centrum.dk and ciliates (Jacobson \& Anderson 1986, Gaines \& Elbrächter 1987, Hansen 1991 a, b, Jeong \& Latz 1994), thus making large heterotrophic dinoflagellates potential competitors with copepods and cladocerans for microplankton prey (Lessard 1991, Hansen 1992). Only a few papers have been published on the trophic role of the small heterotrophic dinoflagellates 15 to $20 \mu \mathrm{m}$ ). These studies suggest that small heterotrophic dinoflagellates mainly feed on nanoflagellates, thereby potentially competing with planktonic ciliates for prey (Bjørnsen \& Kuparinen 1991, Strom 1991). However, small dinoflagellates are within the size range of prey fed upon by their ciliate competitors. Thus, while small dinoflagellates may be competitors with ciliates for food, they are also potential prey for the ciliates.

The aim of the present study was to compare the functional biology of the small heterotrophic dinoflagellate Gymnodinium sp. [ $7 \mu$ m equivalent spherical diameter (ESD)] and the prostomatid ciliate Balanion comatum Wulff (17 $\mu \mathrm{m}$ ESD) in order to answer the fol- 
lowing questions: (1) Are these organisms competitors for nanoplankton prey? (2) Are there any differences in the functional and numerical responses of the 2 organisms when presented with the same prey? (3) Is the ciliate capable of feeding on the smaller dinoflagellate? (4) Can the observed differences be extrapolated to account for the different trophic roles of ciliates and small heterotrophic dinoflagellates in general?

\section{MATERIALS AND METHODS}

We isolated Gymnodinium sp. and Balanion comatum from water samples from the north of the Øresund, Denmark, in September 1995 at a temperature of $15^{\circ} \mathrm{C}$, a salinity of $28 \mathrm{psu}$, and a depth of $10 \mathrm{~m}$. Crude cultures were initially made by adding the cryptophyte Rhodomonas salina (Wislouch) Hill \& Wetherbee to samples of natural sea water. After 1 to 3 wk, cells of $B$. comatum were transferred to a $65 \mathrm{ml}$ tissue culture bottle (Nunclon $\left.{ }^{(}\right)$), isolated using a micropipette and fed $R$. salina. Cultures were not axenic.

A range of prey algae was used (Table 1). The algae used were all observed to swim with a constant speed of less than $100 \mu \mathrm{m} \mathrm{s} \mathrm{s}^{-1}$. Rhodomonas salina and Isochrysis galbana was supplied from the culture collection of the Marine Biological Laboratory in Helsingor, University of Copenhagen. The other algae were obtained from The Scandinavian Culture Center for Algae and Protozoa, Dept of Algae and Fungi, Botanical Institute, University of Copenhagen, Denmark. Algae were grown in B-medium (Hansen 1989) based on Millipore filtered autoclaved sea water (salinity 30 to $32 \mathrm{psu}$ ) at a temperature of $15 \pm 1^{\circ} \mathrm{C}$. Algae were grown in aerated $250 \mathrm{ml}$ Erlenmeyer

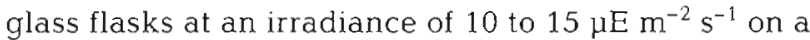
$16 \mathrm{~h}: 8 \mathrm{~h}$ light:dark cycle. Stock cultures of Gymnodinium sp. and Balanion comatum were fed $R$. salina, and maintained in $270 \mathrm{ml}$ transparent tissue bottles $\left(\right.$ Nunclon $^{\otimes}$ ) mounted on a plankton wheel (1 rpm) Otherwise the physical conditions were as stated above.

Cell volumes of algae $(n=20)$ and Balanion comatum $(\mathrm{n}=20)$ were estimated from the linear dimensions of Lugol's fixed cells (final conc. $1 \%$ ) using an inverted Olympus microscope. Algae cells were assumed to be prolate ellipsoids. Due to the shape of the oral apparatus of $B$. comatum, the cell volume was estimated using the formula: $0.1875 W L^{2}$, where $W$ and $L$ are the width and length of cells, respectively (Edler 1979).
Because of the irregular shape of Gymnodinium $\mathrm{sp}$, the cell volume could not be estimated from linear dimensions. Instead, Gymnodinium sp. cells ( $n=20$ cells) fixed in Lugol's (final conc. $1 \%$ ) were recorded using a video camera connected to a monitor and an Olympus ${ }^{\otimes}$ inverted microscope. Cell shapes of Gymnodinium sp. were drawn on a plastic transparency covering the monitor screen. The transparency was digitized using a MOP videoplan (Keytronic, Germany) and cell volumes were estimated by the algorithm of the MOP, which measures the maximum length and width of a 2-dimensional ellipsoid and subsequently rotates the object calculating the volume as a prolate ellipsoid. It is assumed that the shrinkage of predators and preys are of equal magnitude.

Bioenergetics. Growth, ingestion and clearance rates were measured for Balanion comatum and Gymnodinium sp. fed Rhodomonas salina at prey concentration ranging from 200 to 7000 cells $\mathrm{ml}^{-1}$. Experiments were carried out in $270 \mathrm{ml}$ tissue culture bottles in triplicate as batch cultures under conditions described above. Prior to experiments, cultures of Gymnodinium sp. and $B$. comatum were preincubated at the experimental prey concentration for $24 \mathrm{~h}$. Growth rate was measured as the increase in cell number and ingestion rate as the decrease in cells compared to controls without predators. Predator cells were added to the experimental bottles in concentrations which resulted in a decrease of the prey concentrations of 10 to $20 \%$ during the experiment. Samples were fixed in Lugol's (final conc. $1 \%$ ) and at least 400 cells were counted using a $25 \mathrm{ml}$ Utermöhl chamber or in a Sedgwick-Rafter chamber and an inverted Olympus ${ }^{(0)}$ microscope.

Growth rate was calculated assuming exponential growth:

$$
\mu\left(h^{-1}\right)=\frac{\left(\ln N_{1}-\ln N_{0}\right)}{t}
$$

where $N_{0}$ and $N_{1}$ are particle concentration at the beginning and end of the experiment, respectively, $\mu$ is the growth rate, and $t$ is the duration of the experiment (h).

Table 1. Algae used and their corresponding size (as estimated spherical diameter, ESD)

\begin{tabular}{|lrl|}
\hline Species & ESD $(\mu \mathrm{m})$ & Algal class \\
\hline Isochrysis galbana Parke & 4.0 & Prymnesiophyte \\
Chroomonas vectensis Carter & 6.1 & Cryptophyte \\
Plagioselmis prolonga Buchter & 6.6 & Cryptophyte \\
Rhodomonas salina (Wislouch) Hill \& Wetherbee & 7.8 & Cryptophyte \\
Teleaulax amphioxeia (W. Conrad) Hill & 8.5 & Cryptophyte \\
Rhodomonas marina (Dangeard) Lemmermann & 10.3 & Cryptophyte \\
\hline
\end{tabular}


Ingestion rates of Balanion comatum and Gymnodinium sp. were calculated using an iterative model.

$$
\begin{aligned}
& \frac{\mathrm{d} x}{\mathrm{~d} t}=\mu_{x} x-U y \\
& \frac{\mathrm{d} y}{\mathrm{~d} t}=\mu_{y} y
\end{aligned}
$$

The model assumes that the concentrations of predators $(y)$ and prey $(x)$ increase exponentially, with the growth rate constants $\mu_{y}$ and $\mu_{x}$ respectively. The mortality induced by the predator is $U_{y}$, and was calculated iteratively on a computer with steps of $0.01 \mathrm{~h}$. $U$ is the per capita prey uptake per unit time.

Clearance $(F)$ is a function of the per capita prey uptake per unit time $(U)$ and the average prey concentration $(C)$ :

$$
F=\frac{U}{C}
$$

$C$ is calculated according to Frost (1972) to estimate the average cell concentration in an exponentially growing culture.

Growth yield ( $Y$ ) was calculated according to the equation (Fenchel 1982a):

$$
Y=\frac{\mu_{y} V_{y}}{U V_{x}}
$$

where $V_{y}$ and $V_{x}$ are the cell volumes of Balanion comatum or Gymnodinium sp. and Rhodomonas salina, respectively.

Prey size selection. Balanion comatum and Gymnodinium sp. were fed algae ranging in size from 4 to $12 \mu \mathrm{m}$ in order to study prey size preferences (Table 1). The algae were added at a constant biomass (cell number $\times$ cell volume) equivalent to 900 Rhodomonas salina cells $\mathrm{ml}^{-1}$ in the case of Balanion comatum and $1200 R$. salina cells $\mathrm{ml}^{-1}$ in the case of Gymnodinium sp., a biomass which supports approximately $90 \%$ of the maximum growth rate for each of the 2 predators when fed $R$. salina. Otherwise the physical conditions were as described above.

Mixture experiment. This experiment was conducted to investigate the interaction between Balanion comatum and Gymnodinium sp. when they co-occur. Cultures of Gymnodinium sp. and B. comatum were mixed in a suspension of Rhodomonas salina. Controls were run in which $B$. comatum and Gymnodinium sp. were fed $R$. salina in separate cultures. All experiments were carried out in $750 \mathrm{ml}$ tissue culture bottles in triplicate. At intervals of between 8 and $16 \mathrm{~h}, 50 \mathrm{ml}$ was sampled from each bottle and replaced with fresh medium. The experiments were run until food was depleted.

Starvation experiment. Dense exponentially growing cultures of Gymnodinium sp. and Balanion comatum cells were diluted to a concentration of $\sim 500$ predators $\mathrm{ml}^{-1}$ in triplicate culture. After $6 \mathrm{~h}$ (B. comatum) and $12 \mathrm{~h}$ (Gymnodinium sp.), the first sample was taken. At this time no Rhodomonas salina cells were left in the cultures. The number of $B$. comatum and Gymnodinium sp. cells were counted and cell volume was estimated at the time points shown in Fig. 9.

Locomotive pattern. The locomotive pattern of Gymnodinium sp. and Balanion comatum was studied by adding a cell suspension to a $2.7 \mathrm{ml}$ multidish, which was subsequently covered with a cover slip. The multidish was placed under a Nikon ${ }^{\oplus}$ DIAPHOT microscope fitted with a video camera, and cells were recorded at a magnification of between $\times 80$ and $\times 400$. Cells were tracked for at least $1 \mathrm{~s}$, yielding a minimum of 25 video frames per tracked cell. At least 40 cells of each predator were tracked. After recording, the video tape was played frame by frame and the cell positions were marked on plastic transparencies covering the screen. Subsequently, the transparencies were scanned into a computer data file and digitized using the program SigmaScan ${ }^{(}$(Jandel Scientific ${ }^{\circledR}$, CA, USA).

\section{RESULTS}

The ciliate was identified as Balanion comatum from observations made on protargol- and silver-stained specimens in the light microscope (Fig. 1) and with the use of a transmission electron microscope. The cell body is cup shaped, with a flattened oral end. While the cell volume depended on the food concentration (see Fig. 5), the oral disc was of constant size $(9 \mu \mathrm{m})$. The oral disc is surrounded by oral dikinetids, with cilia measuring $8 \mu \mathrm{m}$ in length, and an inner circle of tentacles (length $12 \mu \mathrm{m}$ ); there is 1 tentacle per dikinetid. The average dimension of cells growing at food saturation was approx. $20 \times 15 \mu \mathrm{m}$.

Gymnodinium sp. (Fig. 2) is a spindle-shaped athecate dinoflagellate with an average length of $8 \mu \mathrm{m}$ and a variable width depending on food concentration. The food vacuole is located in the anterior end of the cell. Prey organisms are captured by use of a tow filament and engulfed directly.

Ingestion rates of both Balanion comatum and Gymnodinium $\mathrm{sp}$. increased with prey concentration until a maximum level was reached (Fig. 3). However, data obtained from the 2 organisms were fitted to different equations due to differences in their feeding biology. Balanion comatum ingested about 22 cells before it divided. Thus, the functional response can be considered as a Holling type II functional response. However, Gymnodinium sp. engulfed only about a single prey prior to cell division and ingestion rate is solely based on predator-prey encounter. The functional response of Gymnodinium sp. can therefore be considered as a Holling type I response. 


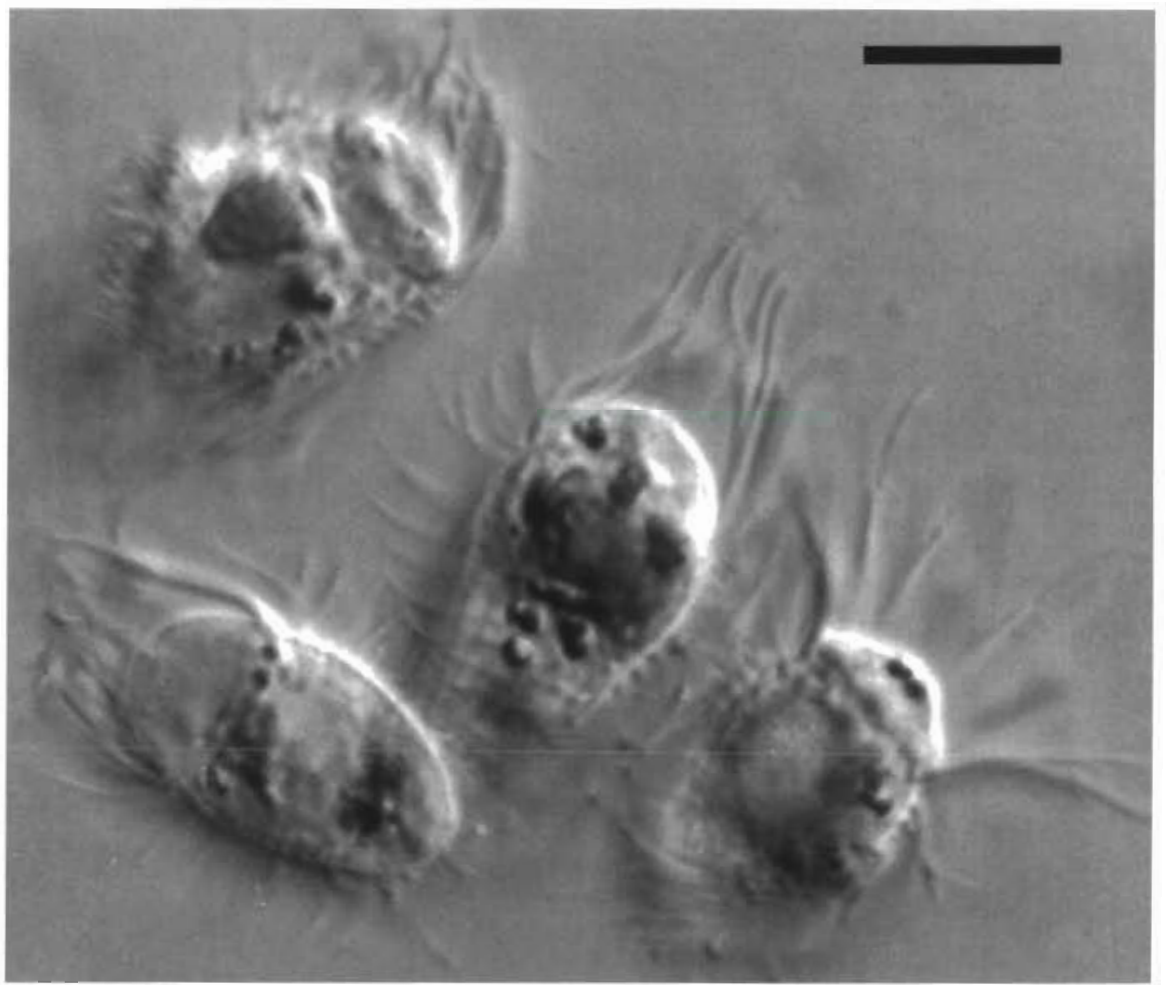

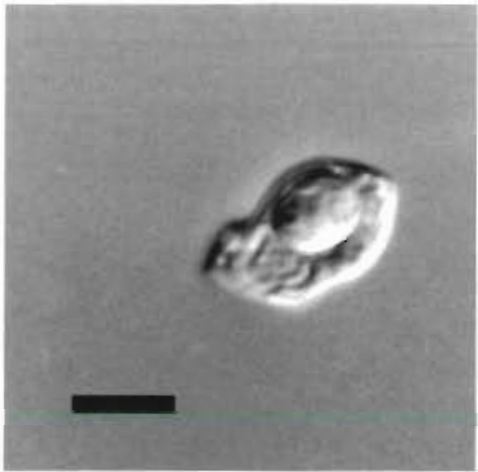

$\Delta$

Fig. 2. Gymnodinium sp. Nomarski contrast interference microscopy. Cells are fixed under a hanging drop with $5 \% \mathrm{OsO}_{4}$. Scale bar $=5 \mu \mathrm{m}$

Fig. 1. Balanion comatum. Nomarski contrast interference microscopy. Cells are fixed under a hanging drop of $5 \% \mathrm{OsO}_{4}$. Scale bar $=10 \mu \mathrm{m}$

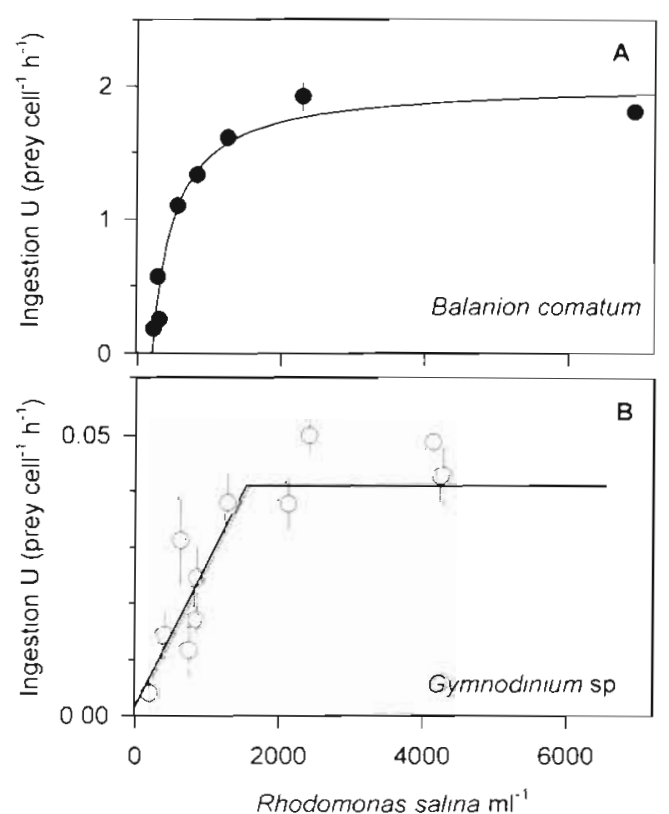

Fig. 3. Ingestion rate as a function of prey concentration. (A) Balanion comatum. The curve is fit to a Michaelis-Menten equation (Holling type [1):

$$
U\left(h^{-1}\right)=\frac{2.027(x-204)}{51.1+(x-204)}
$$

(B) Gymnodinium sp. Curve represents a fit to a Holling type I functional response: $U\left(\mathrm{~h}^{-1}\right)=0.00165+\left(2.71 \times 10^{3}\right) \times$ for $x<1536$ Rhodomonas salina $\mathrm{ml}^{-1}$, and $U\left(\mathrm{~h}^{-1}\right)=0.043 x$ for $x>1536 R$. salina $\mathrm{ml}^{-1}$. Data points represent treatment means $\pm 1 \mathrm{SE}$
Balanion comatum had a maximum ingestion rate of $\sim 2$ Rhodomonas salina cells $\mathrm{h}^{-1}$ (Fig. 3), corresponding to a maximum specific ingestion rate (volume of prey ingested/predator volume) of $\sim 15 \% \mathrm{~h}^{-1}$. The maximum ingestion rate of Gymnodinium sp. was $\sim 0.043 R$. salina cells $\mathrm{h}^{-1}$ (Fig. 3), corresponding to a maximum specific ingestion rate of $\sim 6 \% \mathrm{~h}^{-1}$, which is 2 to 3 times lower than that of $B$. comatum.

The growth rate of Balanion comatum reached a maximum of $0.058 \mathrm{~h}^{-1}$ at a prey concentration of $\sim 1000$ Rhodomonas salina $\mathrm{ml}^{-1}$ (Fig. 4), while Gymnodinium sp. reached a maximum growth rate of $0.039 \mathrm{~h}^{-t}$ at a prey concentration of $\sim 1300 R$. salina $\mathrm{ml}^{-1}$ (Fig. 4).

Due to differences in the functional biology of the ciliate and the dinoflagellate, the threshold prey concentration for growth (defined as the prey concentration at which $\mu=0$ ) was determined differently. The threshold prey concentration for growth for Balanion comatum was determined by the formula:

$$
\mu=\frac{\mu_{\max }\left(x-x_{0}\right)}{K+\left(x+x_{0}\right)}
$$

where $\mu_{\max }$ is the maximum growth rate, $x$ is the actual prey concentration, $x_{0}$ is the threshold prey concentration for growth and $K$ is the prey concentration sustaining $0.5 \mu_{\mathrm{m} \text { ax }}$. Data was iteratively fitted to the model

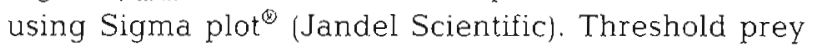
concentration for growth of Gymnodinium sp. was estimated as the intercept when $\mu=0$. The threshold prey 


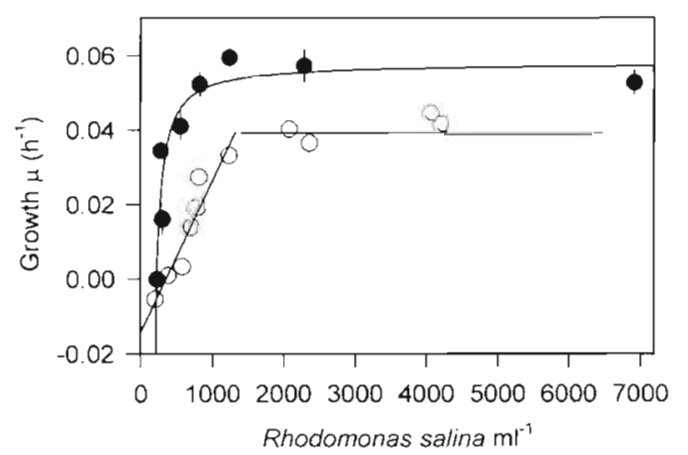

Fig. 4. Growth rate of Balanion comatum ( $\bullet$ ) and Gymnodinium sp. (o) as a function of prey concentration $(x)$. See Table 2 and text for details. Data points represent treatment means $\pm 1 \mathrm{SE}$

concentrations for growth of B. comatum and Gymnodinium sp. were approximately $227 \pm 14( \pm 1 \mathrm{SE})$ and $382 \pm 61$ ( $\pm 1 \mathrm{SE})$ Rhodomonas salina $\mathrm{ml}^{-1}$, respectively Results of these fits are shown in Table 2 .

The cell volume of Balanion comatum increased from $\sim 1100 \mu^{3}$ at low prey concentrations to $\sim 2500 \mu^{3}$ at prey concentrations sustaining maximum growth rates (Fig. 5). The cell volume of Gymnodinium sp. increased from $\sim 70 \mu^{3}$ at low prey concentrations to $-160 \mu^{3}$ at food saturation (Fig. 5).

Gymnodinium sp. and Balanion comatum had a yield of $\sim 68 \pm 10 \%( \pm 1 \mathrm{SE})$ and $32 \pm 8 \%( \pm 1 \mathrm{SE})$, respectively, when cells were growing at maximum growth rates (Fig. 6). Yield decreased at prey concentrations less than $\sim 600$ and $\sim 250$ cells $\mathrm{ml}^{-1}$ for Gymnodinium sp. and B. comatum, respectively (Fig. 6). Maintenance requirements, defined as the specific ingestion rate at $\mu=0$, were low $\left(1\right.$ to $2 \% \mathrm{~h}^{-1}$; Fig. 7$)$ for both species.

The maximum specific clearance of Balanion comatum was $\sim 2$ times higher than that of Gymnodinium sp., $17 \times 10^{5}$ and $8.3 \times 10^{5}$ body volumes $h^{-1}$, respectively (Fig. 8). The maximum absolute clearance of $B$. comatum and Gymnodinium sp. was 2.8 and $0.053 \mu \mathrm{l}$ $\mathrm{h}^{-1}$, respectively (data not shown).

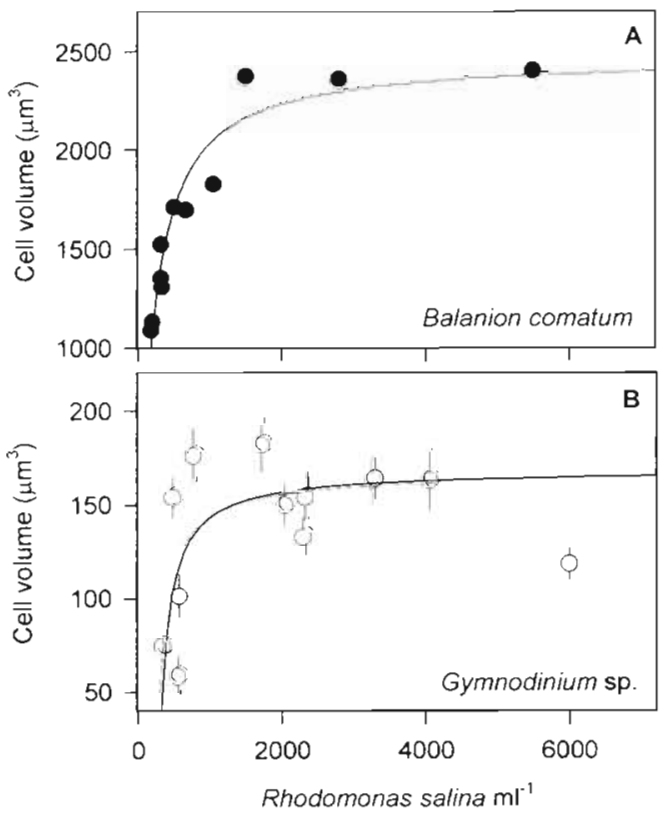

Fig. 5. Cell volume as a function of prey concentration $(x)$ (A) Balanion comatum

$$
V\left(\mu \mathrm{m}^{3}\right)=\frac{2614(x+58)}{338+(x+58)}
$$

and (B) Gymnodinium sp.

$$
V\left(\mu \mathrm{m}^{3}\right)=\frac{168(x-286)}{124+(x-286)}
$$

for prey concentrations $>400$ Rhodomonas salina cells $\mathrm{ml}^{-1}$. Data points represent treatment means $\pm 1 \mathrm{SE}$

When subjected to starvation, Balanion comatum immediately decreased in number and cell volume (Fig. 9). After $50 \mathrm{~h}$, only $10 \%$ of the initial concentration of $B$. comatum was left, and cells had shrunk to $\sim 400 \mu^{3}$ (9 $\mu \mathrm{m}$ ESD). After $60 \mathrm{~h}$, no B. comatum cells were left in the culture. When subjected to starvation, Gymnodinium sp. produced swarmer cells (small fastmoving cells) which had a cell volume of about 60 to $70 \mu^{3}$. One third of cells immediately underwent 1 post feeding cell division and the average cell volume was reduced by $50 \%$ before cells died off. Most of the

Table 2. Balanion comatum and Gymnodinium sp. Values of maximum growth $\left(\mu_{\max }\right)$ and ingestion $\left(U_{\max }\right)$ rates. Due to differences in feeding biology, data on $B$. comatum are fitted to a Holling type II response, while data on Gymnodinium sp. were fitted

\begin{tabular}{|c|c|c|c|c|c|}
\hline Predator & Fit type & Equation & $r^{2}$ & $\mu_{\max } / U_{\max }\left(\mathrm{h}^{-1}\right)$ & $K\left(\right.$ cells $\left.\mathrm{ml}^{-1}\right)$ \\
\hline \multicolumn{6}{|l|}{ Growth } \\
\hline Balanion comatum & Holling II & $\mu\left(\mathrm{h}^{-1}\right)=0.058(x-227) /[315+(x-227)]$ & 0.89 & 0.058 & 315 \\
\hline Gymnodinium sp. & Holling I & $\begin{array}{l}\mu\left(\mathrm{h}^{-1}\right\}=-0.0143+4.06 \times 10^{-5} x \\
x<1318\end{array}$ & 0.90 & 0.039 & 821 \\
\hline \multicolumn{6}{|l|}{ Ingestion } \\
\hline Balanion comatum & Holling II & $U\left(\mathrm{~h}^{-1}\right)=2.027(x-204) /[511+(x-204)]$ & 0.96 & 2.027 & 511 \\
\hline Gymnodinium sp. & Holling I & $\begin{array}{l}U\left(\mathrm{~h}^{-1}\right)=0.00165+2.71 \times 10^{-5} \mathrm{x} \\
x<1536\end{array}$ & 0.59 & 0.043 & 738 \\
\hline
\end{tabular}
to a Holling type I response. $x$ : actual prey concentration; $K$ : prey concentration sustaining $0.5 \mu_{\max }$ 


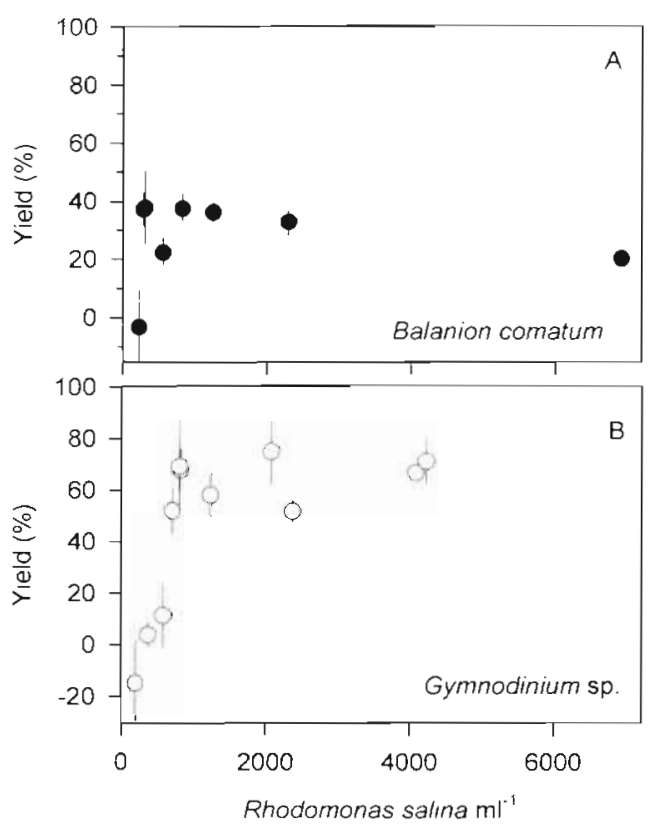

Fig. 6. Yield as a function of prey concentration for (A) Balanion comatum and (B) Gymnodinium sp. Data points represent treatment means $\pm 1 \mathrm{SE}$

Gymnodinium sp. cells (80\%) were left after $150 \mathrm{~h}$ (Fig. 9). Formation of resting cysts was not observed in any of the investigated species.

The prey size spectrum for Gymnodinium sp. is almost identical to that of Balanion comatum (Fig. 10). The optimum prey size was $8 \mu \mathrm{m}$ (ESD). The lower

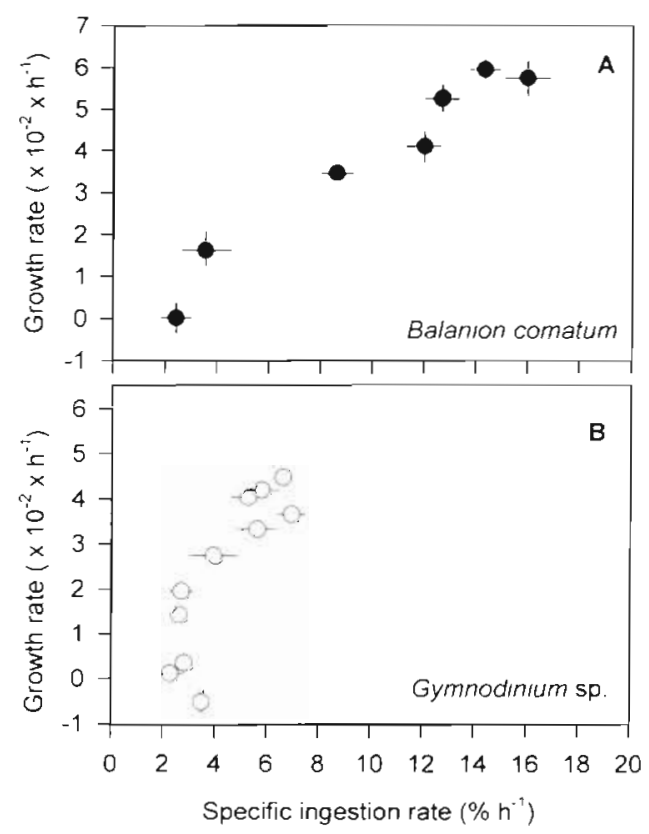

Fig. 7. Growth rate $(\mu)$ as a function of specific ingestion rate (U) for (A) Balanion comatum and (B) Gymnodinium $\mathrm{sp}$

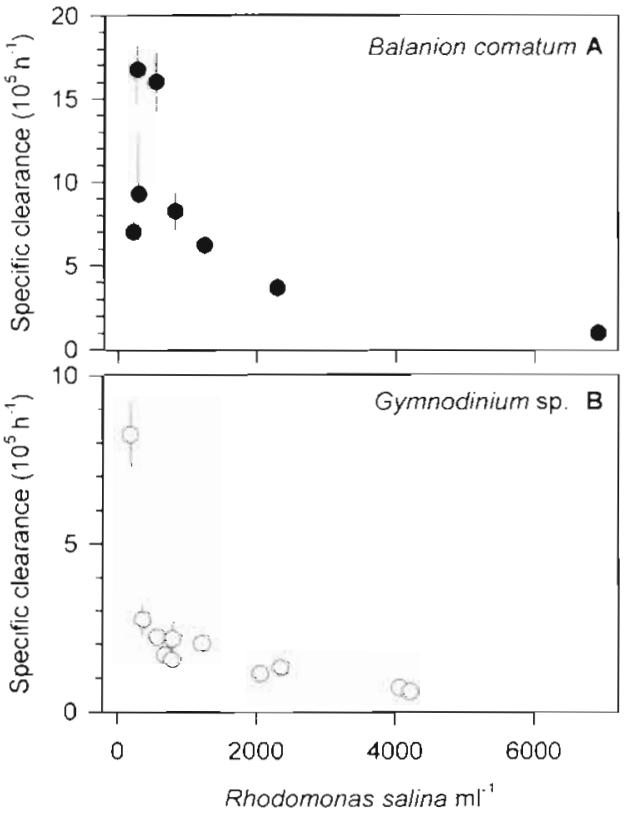

Fig. 8. Specific clearance (body volumes $\mathrm{h}^{-1}$ ) as a function of prey concentration for (A) Balanion comatum and (B) Gymnodinium sp. 1)ata points represent treatment means $\pm 1 \mathrm{SE}$

limit of prey capture was $4 \mu \mathrm{m}$ ESD and the upper limit close to $10 \mu \mathrm{m}$ ESD. Generally there is a good agreement between the prey size spectrum based on growth rate and the one based on ingestion rates. However, in

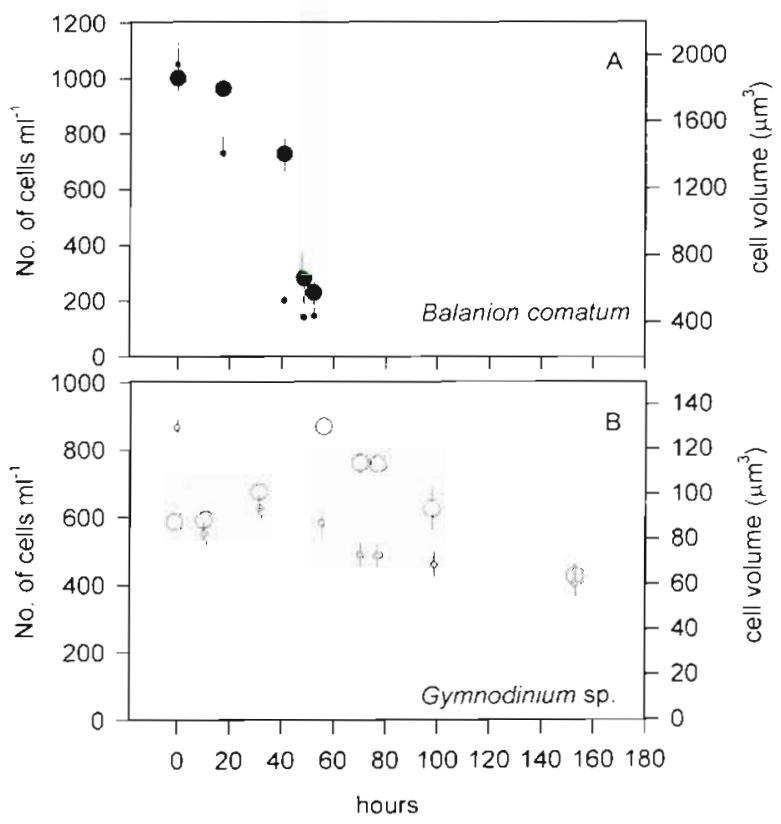

Fig. 9. Starvation. (A) Balanion comatum. The number of predator cells $(1)$ and the volume of the starving predator $(\cdots \cdots)$. (B) Gymnodinium sp. The number of predator cells (O) and the volume of the starving predator $(\cdots 0$.$) . Data points$ represent treatment means $\pm 1 \mathrm{SE}$ 


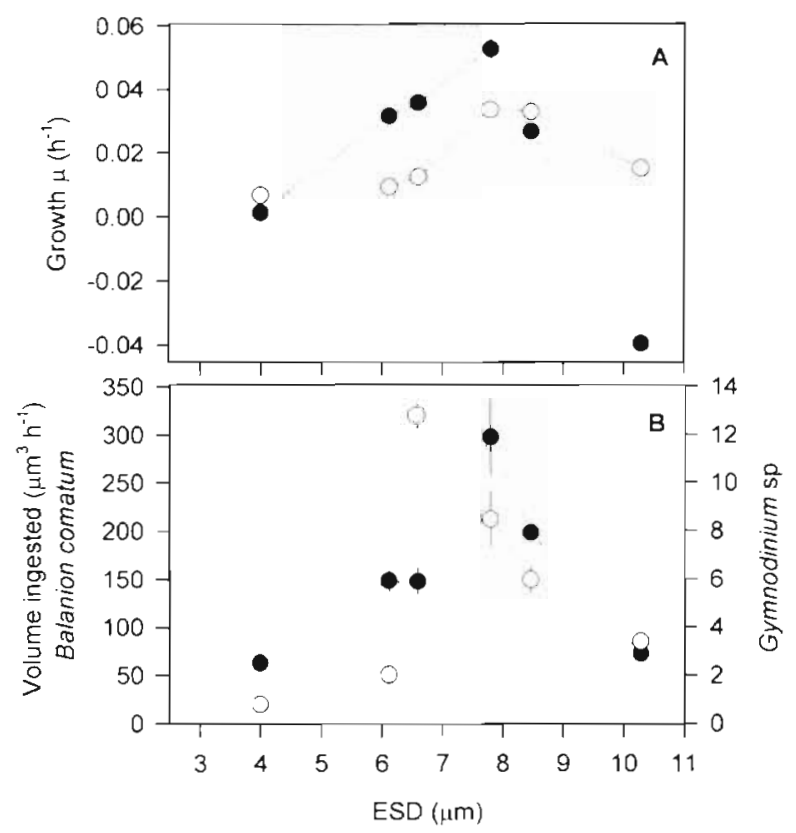

Fig. 10. Prey size spectra. (A) Growth rate $(\mu)\left(h^{-1}\right)$ as a function of prey size (ESD) and (B) ingestion rate as a function of prey size $\left(\mu^{3} \mathrm{cell}^{-1} \mathrm{~h}^{-1}\right)$ for Balanion comatum $(\bullet)$ and Gymnodinium sp. (0). Data points represent treatment means $\pm 1 \mathrm{SE}$

one case (Gymnodinium sp. fed Plagioselmis prolonga) a very high ingestion rate was not reflected in the growth rate, indicating a low growth efficiency.

The average growth rates of Gymnodinium sp. and Balanion comatum obtained when they were grown together on Rhodomonas salina did not differ significantly from growth rates obtained in cultures where they were grown alone on $R$. salina ( $t$-test: Gymnodinium sp., $\mathrm{p}=$ $0.8106, t=0.246 ; B$. comatum, $\mathrm{p}=0.7451, t=0.334)$, indicating that $B$. comatum is unable to feed on Gymnodinium sp. and vice versa (Fig. 11, Table 3).

Gymnodinium sp. cells either drifted passively or swam in an almost straight path with an average speed of $195 \pm 10 \mu \mathrm{m} \mathrm{s}^{-1}$ ( $\pm 1 \mathrm{SE}$ ) corresponding to 25 body lengths $\mathrm{s}^{-1}$. Drifting was never observed in starved Gymnodinium sp. cells. Upon making contact with

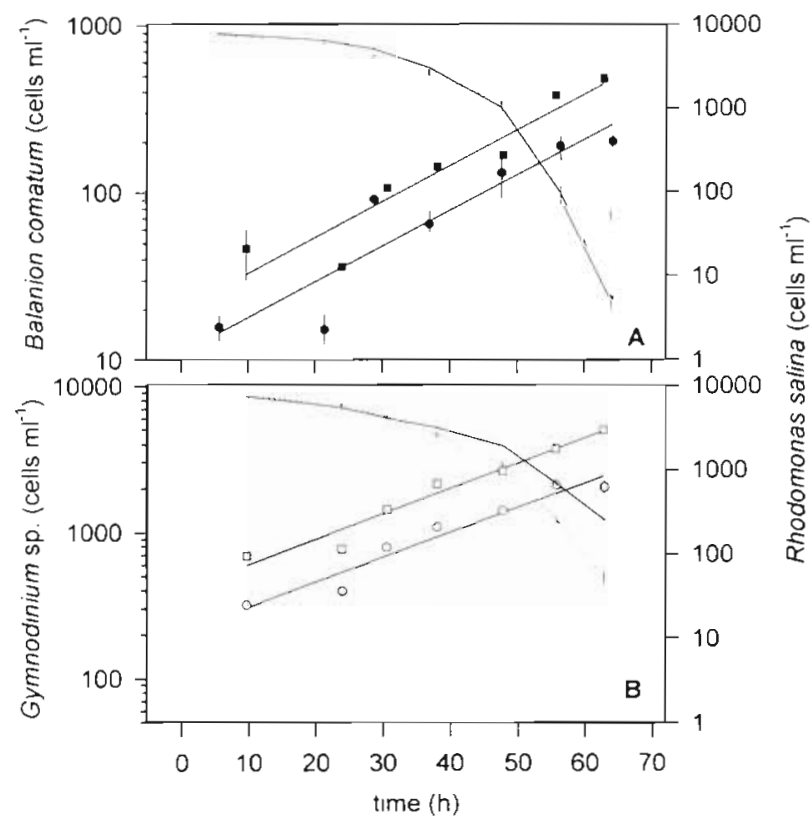

Fig. 11 Mixture experiments. (A) Cell concentration of Balanion comatum in mixed cultures with Gymnodinium sp. and Rhodomonas salina $(\bullet)$ and in the control experiment where Balanion comatum only co-occurs with $R$. salina (a). (B) Cell concentration of Gymnodinium sp. in mixed cultures with Balanion comatum and Rhodomonas salina (o) and in the control experiment where it only co-occurs with $R$. salina (ㅁ). In both plots, dotted and solid curves refer to cell concentration of $R$. salina in the mixed culture and in the control.

respectively. Data points refer to cell concentration $\pm 1 \mathrm{SE}$

other objects, Gymnodinium sp. cells tumbled and subsequently performed a burst with a maximum speed of $6600 \mu \mathrm{m} \mathrm{s}^{-1}$. Thereafter, swimming speed decreased asymptotically to $195 \mathrm{\mu m} \mathrm{s}^{-1}$ or to passive drifting. The distance traveled during a burst was up to $400 \mu \mathrm{m}$. Balanion comatum swam in helices at an average speed of $375 \pm 22 \mu \mathrm{m} \mathrm{s}^{-1}( \pm 1 \mathrm{SE})$ corresponding to 19 body lengths $\mathrm{s}^{-1}$. Bursts were observed with a maximum speed of $1100 \mu \mathrm{m} \mathrm{s}^{-1}$. The burst was stopped drastically and the cell almost stopped swimming for some time $(0.5$ to $1 \mathrm{~s})$ after which the cell resumed its original swimming speed. The distance traveled during bursts was often up to $1000 \mu \mathrm{m}$.
Table 3. Balanion comatum and Gymnodinium sp. Growth rate $\left(\mathrm{h}^{-1}\right)$ in the mix ture experiment. No significant differences in growth rates were observed between control and mixture experiments (for test used see text). n: number of replicates

\begin{tabular}{|llccc|}
\hline Species & Experiment & Growth rate (h) & $\mathrm{r}^{2}$ & $\mathrm{n}$ \\
\hline Gymnodinium sp. & Control & 0.039 & 0.96 & 7 \\
Gymnodinium sp. & Mixture experiment & 0.039 & 0.93 & 7 \\
Balanion comatum & Control & 0.051 & 0.88 & 7 \\
Balanion comatum & Mixture experiment & 0.053 & 0.80 & 7 \\
\hline
\end{tabular}

\section{DISCUSSION}

\section{Prey selection}

Gymnodinium sp. $(7 \mu \mathrm{m})$ and Balanion comatum $(17 \mu \mathrm{m})$ both feed on autotrophic nanoflagellates 4 to $10 \mu \mathrm{m}$ in diameter and may be considered as competitors for similar-sized food. However, to what degree can this ob- 
servation be used to generalise on the competition between small dinoflagellates and ciliates?

Gymnodinium sp. ingests single cells by direct engulfment, which is a common feeding mechanism among heterotrophic dinoflagellates (Gaines \& Elbrächter 1987, Hansen 1991b). We found that Gymnodinium sp. had an optimum prey size corresponding approximately to its own size, which in specific terms is similar to that obtained for Gyrodinium spirale, which also feeds using this feeding mechanism (Hansen 1992). Other feeding mechanisms found among heterotrophic dinoflagellates include pallium feeding and feeding tubes. These feeding mechanisms also allow the dinoflagellate to ingest relatively large prey. In summary, predator:prey size ratios found among the dinoflagellates range between $0.4: 1$ and $7: 1$ (see Table 4). Hence, Gymnodinium sp. does not differ from the large majority of dinoflagellates described so far. Note, however, that Noctiluca scintillans is an exception by being capable of ingestion of a much broader range of prey due its ability to glue prey items into large packages (see Gaines \& Elbrächter 1987, Buskey 1995).

Some studies have suggested that heterotrophic dinoflagellates ingest particles of the size of bacteria (Lessard \& Swift 1985, Strom 1991). The study of Lessard \& Swift (1985) demonstrated uptake of thymidine-labelled bacteria in heterotrophic dinoflagellates, but their investigation did take into account the following: (1) Thymidine may have accumulated in the food chain. Thus, bacteria may have been fed upon by heterotrophic nanoflagellates and ciliates, which subsequently were fed upon by the heterotrophic dinoflagellates. (2) Bacteria may be parts of aggregates of a much larger size, making them available for heterotrophic dinoflagellates. Strom (1991) documented feeding of a Gymnodinium sp. $(12 \mu \mathrm{m})$ on the cyanobacteria Synechococcus sp. $(1.2 \times 2.4 \mu \mathrm{m})$ when presented in mixture with the prymnesiophyte Isochrysis galbana $(4.5 \mu \mathrm{m})$. However, Synechococcus sp. is a rather large autotrophic bacteria with a volume which is 20 to 30 times that of marine heterotrophic bacteria in natural environments (Lee \& Fuhrmann 1987, Simon \& Azam 1989).

An important observation is that the presently investigated Gymnodinium sp. has a lower prey size limit of about $4 \mu \mathrm{m}$, suggesting that small dinoflagellates $(<10 \mu \mathrm{m})$ do not feed on single cells of heterotrophic bacteria, unlike most other groups of nanoflagellates < 10 um (Fenchel 1982a, Eccleston-Parry \& Leadbeater 1994). In conclusion, no experiments have so far documented, beyond reasonable doubt, that heterotrophic dinoflagellates are able feed on prey in the size range of naturally occurring heterotrophic bacteria in marine environments.
A prey size spectrum has not previously been established for prostomatid ciliates. However, the freshwater species Balanion planctonicum (15 $\mu \mathrm{m}$ ) preyed upon a $10 \mu \mathrm{m}$ flagellate (Müller 1991, Sommaruga \& Psenner 1993), while a marine Balanion sp. (34 $\mu \mathrm{m})$ grew best on the $17 \mu \mathrm{m}$ dinoflagellate Heterocapsa triqueta (Stoecker et al. 1986). We found that the $17 \mu \mathrm{m}$ Balanion comatum grew best on Rhodomonas salina of $8 \mu \mathrm{m}$, indicating a general predator:prey ratio of $2: 1$ for species belonging to the genus Balanion. This is in contrast to aloricate oligotrich ciliates, which have an optimum predator:prey size ratio of about 8:1 (Jonsson 1986, 1987), but similar to loricate oligotrichs (tintinnids), which are able to ingest prey of a size which corresponds to a predator:prey size ratio of approx. $2.5: 1$ (Heinbokel 1978). Thus, it appears that small (<20 $\mu \mathrm{m})$ heterotrophic dinoflagellates compete with small $(<20 \mu \mathrm{m})$ prostomatids and loricate and aloricate oligotrichs $(40$ to $60 \mu \mathrm{m})$ for prey in the 4 to $10 \mu \mathrm{m}$ size range.

It is surprising that Balanion comatum apparently cannot catch Gymnodinium sp. cells, even though Gymnodinium sp. is of an optimal prey size for $B$. comatum. We believe that the reason for this is that Gymnodinium sp. performs a fast escape response when making contact with objects, while the algae used in the experiment do not, thereby making it impossible for the ciliate to catch the dinoflagellate. While data on swimming behavior in heterotrophic dinoflagellates are available in the literature (Jacobson \& Anderson 1986, Strom \& Buskey 1993), this is, to our knowledge, the first time burst swimming has been reported in dinoflagellates. We have observed burst swimming in other small gymnodinoid dinoflagellates (unpubl. obs.), indicating that this may not be an unique trait for this species.

\section{Bioenergetics}

The growth rate of the ciliate Balanion comatum was higher than that of the dinoflagellate Gymnodinium sp. at prey concentrations which supported balanced growth (Figs. $3 \& 4$ ), indicating that the ciliate may potentially out-compete the dinofiagellate in natural environments. The maximum growth rate of Gymnodinium sp. is close to the expected value which can be calculated from published relationships between growth rate and size (Hansen 1992, Sherr \& Sherr 1994). The maximum growth rate of $B$. comatum is almost identical to the growth rate obtained for the freshwater $B$. planctonicum at a similar temperature (Müller 1991). The maximum growth rate of $B$. comatum is relatively low when compared to the expected maximum growth rate calculated from relationships between maximum growth rate and size of ciliates 
(Fenchel \& Finlay 1983, Montagnes 1996 and references therein). However, the maximum growth rate of $B$. comatum is comparable to or even higher that that of other planktonic (and larger) ciliates feeding on nanoplankton (Table 4).

Gymnodinium sp. and Balanion comatum have almost similar threshold prey concentrations for

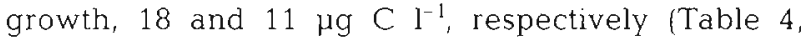
Fig. 4). Values of threshold prey concentrations for growth taken from the literature are shown in Table 4. The threshold prey concentrations for growth of Gymnodinium $5 p$. and $B$. comatum are both at the lower end of reported values within the 2 groups. Considerable variation is found in the estimates of the threshold prey concentrations for growth among both ciliates and heterotrophic dinoflagellates. However, data for ciliates and heterotrophic dinoflagellates fall within the same range. Consequently, no relationship between predator size and threshold prey concentration is found in either of the groups (Table 4). The high variability may reflect different 'strategies' within the groups, but may equally be explained by the difficulty in obtaining reliable results. In fact, some of the obtained threshold values are extremely high (200 to $300 \mu \mathrm{g} \mathrm{C} \mathrm{l}^{-1}$ ). Laboratory data may overestimate the threshold prey concentration if (1) the prey is of a suboptimal size or quality (see Table 4), (2) the prey is not evenly distributed during incubation or (3) prey con- centration is being depleted during incubation. In fact, often only the initial prey concentration is measured. Thus, at present it is impossible to tell if there are significant differences in threshold prey concentration for growth between ciliates and dinoflagellates.

So far most laboratory experiments have been carried out under steady state conditions. However, steady state conditions are rarely found in nature, because pelagic environments are indeed heterogeneous in time and space (Andersen \& Sørensen 1986, Owen 1989, Franks 1995). Also, selective predation by metazooplankton may affect populations of ciliates and small dinoflagellates differently.

\section{Adaptations to a heterogeneous environment}

Protists that live in heterogeneous environments have evolved adaptations to cope with fluctuations in food availability, a phenomenon often referred to as a feast and famine existence. Such adaptations can involve complex life cycles (resting cysts and swarmer formation) and the ability to regulate metabolism when food conditions change.

Formation of resting cysts is widespread among ciliates and heterotrophic dinoflagellates (e.g. Goodman 1987. Fenchel 1990). Resting cysts have not been reported among species in the genera Balanion and

Table 4. Maximum growth rates and threshold prey concentration taken from the literature for growth of heterotrophic dinoflagellates and planktonic ciliates. Literature values were converted to carbon assuming $0.12 \mathrm{pg} \mathrm{C} \mathrm{mm}^{-3}$ (Strathmann 1967 ). A

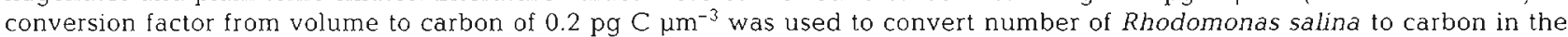
present experiment (data not shown). Data on growth rates are adjusted to $15^{\circ} \mathrm{C}$ using $Q_{10}=2.8$. nd $=$ not determined

\begin{tabular}{|c|c|c|c|c|c|c|}
\hline Species & $\begin{array}{c}\text { Predator } \\
\text { ESD } \\
(\mu \mathrm{m})\end{array}$ & $\begin{array}{c}\text { Max. } \\
\text { growth } \\
\text { rate, } \mu\left(\mathrm{h}^{-1}\right)\end{array}$ & $\begin{array}{l}\text { Threshold } \\
\left(\mu \mathrm{gCl}^{-1}\right)\end{array}$ & Prey species & $\begin{array}{l}\text { ESD } \\
(\mu \mathrm{m})\end{array}$ & Source \\
\hline \multicolumn{7}{|l|}{ Dinoflagellates } \\
\hline Gymnodinium sp & 7 & 0.043 & 18 & Rhodomonas salina & 8 & This study \\
\hline Gymnodinium sp. & 12 & 0.043 & 10 & Isochrysis galbana/Synechococcus sp. & $4.5 / 1.5$ & Strom (1991) \\
\hline Gyrodinium spirale & 27 & 0.027 & 246 & Heterocapsa triquetra & 16 & Hansen (1992) \\
\hline Oblea rotunda & 23 & 0.017 & 20 & Ditylum brightwellii & 23 & Strom \& Buskey (1993) \\
\hline Oblea rotunda & 23 & 0.010 & 50 & Dunaljella tertiolecta & 6.5 & Strom \& Buskey (1993) \\
\hline Protoperidinium crassipes & 73 & 0.008 & 247 & Gonyaulax polyedra & 37 & Jeong et al. (1994) \\
\hline Protopendinium of divergens & $s \quad 61$ & 0.013 & 262 & Gonyaulax polyedra & 37 & Jeong et al. (1994) \\
\hline Protoperidinium huberi & 48 & 0.017 & 10 & Ditylum brightwellii & 23 & Buskey et al. (1994) \\
\hline \multicolumn{7}{|l|}{ Ciliates } \\
\hline Eutintunnus pectinis & 31 & 0.054 & 14 & Isochrysis galbana/Monochrysis luthen & nd & Helnbokel (1978) \\
\hline Favella azorica & nd & 0.054 & 17 & Heterocapsa triquetra & 16 & Kamiyama (1997) \\
\hline Favella ehrenbergii & 57 & 0.034 & 6 & Heterocapsa triquetra & 16 & Hansen (1995) \\
\hline Favella taraikaensis & nd & 0.048 & 10 & Heterocapsa triquetra & 16 & Kamiyama (1997) \\
\hline Tintinnopsis acuminata & 24 & 0.043 & 15 & Isochrysis galbana & 5 & Verity (1985) \\
\hline Tintinnopsis vasculum & 51 & 0.050 & 15 & Dicrateria inornate & nd & Verity (1985) \\
\hline Lohmaniella spiralis & 31 & 0.037 & 8 & Pyramimonas $\mathrm{sp}$ & 6 & Jonsson (1986) \\
\hline Strobilidium neptuni & 60 & 0.059 & 325 & Chroomonas salina & 8 & Montagnes (1996) \\
\hline Strobilidium veniliae & 56 & 0.026 & 75 & Isochrysis galbana:Chroomonas salina (1:1) & $5.5: 8$ & Montagnes (1996) \\
\hline Strombidinopsis cheshiri & 63 & 0.037 & 6 & Thalassiosira pseudonana & 4 & Montagnes et al. (1996) \\
\hline Strombidium reticulatum & 42 & 0.049 & 8 & Pyramimonas sp. & 6 & Jonsson (1986) \\
\hline Strombidium siculum & 38 & 0.023 & 16 & Thalassiosira pseudonana & 4 & Montagnes (1996) \\
\hline Balanion comatum & 17 & 0.058 & 11 & Rhodomonas salina & 8 & This study \\
\hline
\end{tabular}


Gymnodinium and none of our isolates formed resting cysts. However, we cannot totally exclude cyst production in these genera, because cyst formation can be clone specific and even selected against within a few generations (Fenchel 1989).

Production of swarmers was only observed in Gymnodinium sp. in the present study. Reports on the existence of swarmer cells is very rare in heterotrophic dinoflagellates. To our knowledge only the naked heterotrophic dinoflagellates Polykrikos kofoidii (MoreyGaines \& Ruse 1980) and Gymnodinium fungiforme (Spero \& Moreé 1981) have been described to include swarmers in their life cycles. Production of swarmers is unknown in planktonic ciliates, but is common in benthic ciliates (e.g. Fenchel 1990).

The ability to slow down metabolism to a minimum is known among protists (e.g. Fenchel 1982b, 1989, 1990). Some ciliates can survive for a period corresponding to 40 times their own minimum generation time (Fenchel 1990). However, the few planktonic ciliates studied so far are not able survive for very long when starved, only approx. 2 to 3 minimum generation times (Fenchel 1989, Montagnes 1996). In this respect. Balanion comatum is no exception; it is able to starve for $\sim 4$ times the minimum generation time. Reports on the ability of heterotrophic dinoflagellates to reduce metabolism when starved are sparse. The heterotrophic dinoflagellate Gyrodinium spirale can prolong survival by reducing its metabolism (Hansen 1992). However, the question of how long they are able to survive was not addressed. Jeong \& Latz (1994) found that the large planktonic heterotrophic dinoflagellate Protoperidinium divergens survived for at least 9 times its minimum generation time, while Strom (1991) reported on a Gymnodinium sp. which was able to starve more than 30 times its minimum generation time. Our Gymnodinium sp. was able to starve for more than 10 times its own minimum generation time. Thus, although the information on the ability of planktonic ciliates and heterotrophic dinoflagellates to prolong survival is limited, the data suggest that heterotrophic dinoflagellates may be able to cope better with starvation than planktonic ciliates.

What are the benefits of prolonging survival for the dinoflagellate? Generally, prolonged survival will give the the organism more time to encounter patches in time or space. A compilation of swimming speed data on ciliates and dinoflagellates presented in Buskey et al. (1993) and Hansen et al. (in press) suggest that ciliates generally swim 2 times faster than dinoflagellates, although the variation is large. The maximum distance travelled for an organism is a function of swimming speed, time and tumbling frequency. In the case of Gymnodinium sp., a cell subjected to starvation is able to travel about $100 \mathrm{~m}$ assuming a speed on $195 \mu \mathrm{m} \mathrm{s}^{-1}$. a non-tumbling swimming pattern, and a survival time of $150 \mathrm{~h}$. However, due to the production of swarmers during starvation, the 'genome' of the cell almost doubles the potential distance travelled (200 m). In the case of Balanion comatum, the maximum distance travelled is about $75 \mathrm{~m}$ assuming a speed of $376 \mu \mathrm{m} \mathrm{s}^{-1}$ and a survival time of 55 h. Thus, Gymnodinium sp. has potentially a competitive advantage compared to $B$. comatum when food is patchy in time and space.

\section{Metazooplankton grazing on ciliates and small dinoflagellates}

Grazing by metazooplankton on ciliates has been reported to range from insignificant to important (Stoecker \& Sanders 1985, Wiadnyana \& Rassoulzadegan 1989, Fessenden \& Cowles 1994, Nielsen \& Kiørboe 1994). Field and laboratory experiments have shown that the greatest grazing impact on the ciliate stock by copepods is when phytoplankton concentrations are low and dominated by small phytoflagellates (e.g. Jonsson \& Tiselius 1990, Nielsen \& Kiørboe 1994, Atkinson 1996). However, the swimming behavior of the ciliates also plays a role. Some ciliates, like Strobilidium spp. and Myrionecta rubra, are able to escape by burst swimming (3000 to $\left.7000 \mu \mathrm{m} \mathrm{s} \mathrm{s}^{-1}\right)$ when attacked by metazoan predators (Jonsson \& Tiselius 1990, Gilbert 1994). Data on metazooplankton grazing on small heterotrophic dinoflagellates are lacking However, laboratory experiments on prey size selection by copepods suggest that particles the same size as Gymnodinium sp. are retained with an efficiency which is less than $10 \%$ of that obtained on particles the same size as Balanion comatum (Frost 1972, Nival \& Nival 1976, Berggreen et al. 1988). In conclusion, the grazing impact on ciliates by metazooplankton might under some conditions be much higher than that on small heterotrophic dinoflagellates.

Acknowledgements. We are grateful to the Scandinavian Culture Collection, Botanical Institute, Department of Fungi and Algae, Copenhagen University, which provided most of the algal cultures. We are indebted to Christine Mogelvang Nielsen and Birgit Brander for technical assistance. We thank Tom Fenchel for suggesting the ingestion rate calculations and Bent Vismann for setting up the computer model used in the calculation of feeding rates. We also thank David Montagnes and Cathenne Bernard for constructive criticism. This work was funded by the Danish Natural Science Research Council Contract No. 9502163-28808.

\section{LITERATURE CITED}

Andersen P, Sorensen HM (1986) Population dynamics and trophic coupling in pelagic microorganisms in eutrophic coastal waters. Mar Ecol Prog Ser 33:99-109 
Atkinson A (1996) Subantarctic copepods in an oceanic, low chlorophyll environment: ciliate predation, food selectivity and impact on prey populations. Mar Ecol Prog Ser 130: $85-96$

Beers JR, Stewart GL (1967) Micro-zooplankton in the euphotic zone at five locations across the California current. J Fish Res Bd Can 24:2053-2068

Berggreen U, Hansen B, Kiorboe T (1988) Food size spectra, ingestion and growth of the copepod Acartia tonsa during development: implications for determination of copepod production. Mar Biol 99:341-352

Bjornsen PK, Kuparinen J (1991) Growth and herbivory by heterotrophic dinoflagellates in the southern ocean, studied by microcosm experiments. Mar Biol 109:397-405

Buskey EJ (1995) Growth and bioluminescence of Noctiluca scintillans on varying algal diets. J Plankton Res 17(1): $29-40$

Buskey EJ, Coulter CJ, Brown SL (1994) Feeding, growth and bioluminescence of the heterotrophic dinoflagellate Protoperidinium huberi. Mar Biol 121:373-380

Buskey EJ, Coulter C, Strom S (1993) Locomotory patterns of microzooplankton: potential effects on food selectivity of larval fish. Bull Mar Sci 53(1):29-45

Eccleston-Parry JD, Leadbeater BSC (1994) A comparison of the growth kinetics of six marine heterotrophic nanoflagellates fed with one bacterial species. Mar Ecol Prog Ser 105:167-177

Edler L (ed) (1979) Recommendations on methods for marine biological studies in the Baltic sea. Phytoplankton and chlorophyll. The Baltic Marine Biologist publication, Malmö no. 5:1-38

Fenchel T (1982a) Ecology of heterotrophic microflagellates II. Bioenergetics and growth. Mar Ecol Prog Ser 8:225-231

Fenchel T (1982b) Ecology of heterotrophic microflagellates III. Adaptations to heterogeneous environments. Mar Ecol Prog Ser 9:25-33

Fenchel $T$ (1989) Adaptations to a feast and famine existence in protozoa. In: Wieser W, Gnaiger G (eds) Energy transformation in cells and organisms. Georg Thieme Verlag, Stuttgart. p 290-295

Fenchel T (1990) Adaptive significance of polymorphic life cycle in protozoa: responses to starvation and refeeding in two species of marine ciliates. J Exp Mar Biol Ecol 136: $159-177$

Fenchel T, Finlay BJ (1983) Respiration rates in heterotrophic, free-living protozoa. Microb Ecol 9:99-122

Fessenden L, Cowles TJ (1994) Copepod predation on phagotrophic ciliates in Oregon coastal waters. Mar Ecol Prog Ser 107:103-111

Franks PJS (1995) Thin layers of phytoplankton: a model of formation by near-interstitial wave shear. Deep Sea Res 42:75-91

Frost BW (1972) Effects of size and concentration of food particles on the feeding behavior of the marine planktonic copepod Calanus pacificus. Limnol Oceanogr 17:805-815

Gaines G, Elbrächter M (1987) Heterotrophic nutrition. In Taylor FJR (ed) The biology of dinoflagellates. Blackwell, Oxford, p 224-268

Gilbert JJ (1994) Jumping behavior in the oligotrich ciliate Strobilidium velox and Halteria grandinella, and its significance as a defense against rotifer predators. Microb Ecol 27:189-200

Goodman DK (1987) Dinoflagellate cysts in ancient marine and modern marine sediments. In Taylor FJR (ed) The biology of dinoflagellates. Blackwell, Oxford, p 649-722

Hansen PJ (1989) The red tide dinoflagellate Alexandrium tamarense: effects on behaviour and growth of a tintinnid ciliate Mar Ecol Prog Ser 53:105-116

Hansen PJ (1991a) Dinophysis-a planktonic dinoflagellate genus which act both as a prey and a predator of a ciliate Mar Ecol Prog Ser 69:201-204

Hansen PJ (1991b) Quantitative importance and trophic role of heterotrophic dinoflagellates in a coastal pelagial food web. Mar Ecol Prog Ser 73:253-261

Hansen PJ (1992) Prey size selection, feeding rates and growth dynamics of heterotrophic dinoflagellates with special emphasis on Gyrodinium spirale. Mar Biol 114: $327-334$

Hansen PJ (1995) Growth and grazing response of a ciliate on the red tide dinoflagellate Gyrodinium aureolum in monoculture and in mixture with a non-toxic alga. Mar Ecol Prog Ser 121:65-72

Hansen PJ, Bjornsen PK, Hansen B (in press) Zooplankton grazing and growth: scaling within the $2-2000 \mu \mathrm{m}$ body size range. Limnol Oceanogr

Heinbokel JF (1978) Studies on the functional role of tintinnids in the Southern California Bight. I. Grazing and growth rates in laboratory cultures. Mar Biol 47:177-189

Jacobson DM. Anderson DM (1986) Thecate heterotrophic dinoflagellates: feeding behavior and mechanisms. J Phycol 22:249-258

Jeong HJ, Latz MII (1994) Growth and grazing rates of the heterotrophic dinoflagellate Protoperidinium spp. on red tide dinoflagellates. Mar Ecol Prog Ser 106:173-185

Jonsson PR (1986) Particle size selection, feeding rates and growth dynamics of marine oligotrichous ciliates (Ciliophora: Oligotrichina). Mar Ecol Prog Ser 33:265-277

Jonsson PR (1987) Photosynthetic assimilation of inorganic carbon in marine oligotrich ciliates (Ciliophora, Oligotrichina). Mar Microb Food Webs 2:55-68

Jonsson PR, Tiselius P (1990) Feeding behaviour, prey detection and capture efficiency of the copepod Acartia tonsa feeding on planktonic ciliates. Mar Ecol Prog Ser 60:35-44

Kamiyama T (1997) Growth and grazing response of tintinnıd ciliates feeding on the toxic dinoflagellate Heterocapsa circularisquama. Mar Biol 128:509-515

Lee S, Furhman JA (1987) Relationships between biovolume and biomass of naturally derived marine bacterioplankton. Appl Environ Microbiol 53(6):1298-1303

Lessard EJ (1991) The tropic role of heterotrophic dinoflagellates in diverse marine environments. Mar Microb Food Webs 5(1):49-58

Lessard EJ, Swift E (1985) Species-specific grazing rates of heterotrophic dinoflagellates in oceanic waters, mesaured with a dual-label radioisotope technique. Mar Biol 87 $289-296$

Montagnes DJS (1996) Growth responses of planktonic ciliates in the genera Strobilidium and Strombidium. Mar Ecol Prog Ser 130:241-254

Montagnes DJS, Berger JD, Taylor FJR (1996) Growth rate of the marine ciliate Strombidinopsis cheshiri Snyder and Ohman as a function of food concentration and interclonal variability. J Exp Mar Biol Ecol 206:121-132

Montagnes DJS, Lynn DH, Roff JC, Taylor W (1988) The annual cycle of heterotrophic planktonic ciliates in the waters surrounding the Isles of Shoals, Gulf of Maine: an assessment of theır tropic role. Mar Biol 88:21-30

Morey-Gaines G, Ruse RH (1980) Encystment and reproduction of the predatory dinoflagellate, Polykrikos kofoidi Chatton (Gymnodiniales). Phycologia 19:230-236

Müller H (1991) Pseudobalanion planctonicum (Ciliophora Prostomatida): ecological significance of an algivorous nanociliate in a deep meso-eutrophic lake. J Plankton Res 13:247-262 
Nielsen TG, Kiorboe T (1994) Regulation of zooplankton biomass and production in a temperate, coastal ecosystem. 2 . Ciliates. Limnol Oceanogr 39:508-519

Nival P. Nival S (1976) Particle retention efficiencies of a herbivorous copepod, Acartia clausii (adult and copepodite stages): effects on grazing. Limnol Oceanogr 21. $24-38$

Owen RW (1989) Microscale and finescale variations of small plankton in coastal and pelagic environments. J Mar Res 47:197-240

Sherr EB, Sherr EB (1994) Bacterivory and herbivory: key roles of phagotrophic protists in pelagic food webs. Microb Ecol 28:223-235

Simon M. Azam F (1989) Protein content and protein synthesis rates of planktonic marine bacteria. Mar Ecol Prog Ser 51:201-213

Smetacek V (1981) The annual cycle of protozooplankton in the Kiel Bight. Mar Biol 63:1-11

Sommaruga R, Psenner R (1993) Nanociliates of the order Prostomatida: their relevance in the microbial food web of a mesotrophic lake. Aquat Sci 55:179-187

Spero HJ, Moreé MD (1981) Phagotrophic feeding and its importance to the life cycle of the holozoic dinoflagellate Gymnodinium fungiforme. J Phycol 17:43-51

Editorial responsibility: Otto Kinne (Editor), Oldendorf/Luhe, Germany
Stoecker DK, Cucci TL, Hulburt EM, Yentsch CM (1986) Selective feeding by Balanion sp. (Ciliata: Balanionidae) on phytoplankton that best support its growth. J Exp Mar Biol Ecol 95.113-130

Stoecker DK, Sanders NK (1985) Differential grazing by Acartia tonsa on a dinoflagellate and a tintinnid. J Plankton Res 7:85-100

Strathmann RP (1967) Estimating the organic carbon content of phytoplankton from cell volume or plasma volume. Limnol Oceanogr 12:965-977

Strom SL (1991) Grazing and growth rates of the herbivorous dinoflagellate Gymnodinium sp. from the subarctic Pacific Ocean. Mar Ecol Prog Ser 78:103-113

Strom SL, Buskey EJ (1993) Feeding, growth, and behavior of the thecate heterotrophic dinoflagellate Oblea rotunda. Limnol Oceanogr 38:965-977

Verity PG (1985) Grazing, respiration, excretion, and growth rates of tintinnids. Limnol Oceanogr 30:1268-1282

Verity PG (1991) Measurements and simulation of prey uptake by marine planktonic ciliates fed plastidic and aplastidic nanoplankton. Limnol Oceanogr 36:729-750

Wiadnyana NN, Rassoulzadegan F (1989) Selective feeding of Acartia clausi and Centropages typicus on microzooplankton. Mar Ecol Prog Ser 53:37-45

Submitted: July 14, 1997; Accepted: September 22, 1997 Proofs received from author(s): November 3, 1997 